\title{
Seryjne zabójstwo w ujęciu resocjalizacji ${ }^{1}$
}

\section{Serial homicide in terms of rehabilitation}

\section{Streszczenie:}

Autor skupia się na zjawisku seryjnego zabójstwa. Na początku wyjaśnia podstawowe pojęcie, w tym także pojęcia pokrewne, takie jak zabójstwo impulsywne oraz zabójstwo masowe. W dalszej części porusza temat motywacji - omawia najczęstsze motywy seryjnych zabójców. Autor zwraca również uwagę na wpływ dzieciństwa i środowiska zewnętrznego na działalność zabójców, daje obraz tego, w jaki sposób seryjni zabójcy stają się skłonni do popełniania swoich czynów. W końcowej części artykułu skupia się na możliwości oddziaływań resocjalizacyjnych wobec sprawców seryjnych zabójstw oraz ich sensie. W szczególności, w tych przypadkach, podkreśla wartość izolacji więziennej.

Słowa kluczowe: seryjne zabójstwo, motywacja, środowisko zewnętrzne, dzieciństwo, resocjalizacja

\begin{abstract}
:
This article focuses on the phenomenon of serial homicide. At the outset the primary concept of the homicide is explained, including related concepts, such as: the spree killers, and the mass murder. A theme of serial killers motivation is tackled in the following part. The article draws attention to the impact of childhood and the external environment on the criminal act, explains how serial killers have become willing to commit their deeds. The final section of the article focuses on the possibility of rehabilitation interactions on perpetrators of serial murders and their meaning. In these cases, it especially highlights the value of prison isolation.
\end{abstract}

Keywords: serial homicide, motivation, external environment, childhood, rehabilitation

\footnotetext{
$1 \mathrm{Na}$ podstawie pracy licencjackiej „Seryjne zabójstwo w świetle resocjalizacji” napisanej pod kierunkiem dr Piotra Krzywickiego.
} 
Mateusz Caban - Seryjne zabójstwo...

Seryjni zabójcy są rzadkością w naszej społeczności, jednak kiedy już się ujawnią, w sposób zazwyczaj wstrząsający, nie sposób o nich nie usłyszeć. Pojawia się pytanie, co jest przyczyną takiego postępowania i jakie motywacje kierują sprawcami seryjnych zabójstw? Jakie możliwości resocjalizacyjne można wobec nich zastosować, kiedy już zostaną ujęci i czy mają one jakikolwiek sens? W niniejszym artykule przedstawiony zostanie wpływ środowiska zewnętrznego i znaczenie dzieciństwa w odniesieniu do ich postępowania. Będzie także część poświęcona aspektowi resocjalizacji wobec przestępców tej kategorii. Na początku jednak zostaną wyjaśnione podstawowe pojęcia związane z seryjnym zabójstwem oraz pojęcia pokrewne.

\section{Seryjny zabójca}

Pojęcie seryjny zabójca zostało wymyślone i wprowadzone do powszechnego użytku w roku 1978 przez Roberta Resslera, agenta Federalnego Biura Śledczego (FBA). Ressler zastosował je do opisania pewnego gatunku zabójstw, a konkretniej do określenia morderców wielokrotnie dopuszczających się swoich zwyrodniałych czynów. Należy zauważyć, że żaden z morderców nie zabijał dla zysku w sensie materialnym czy z jakiegoś innego powodu, który mógłby zrozumieć normalny człowiek, lecz prawdopodobnie dla samej przyjemności pozbawiania kogoś życia². W przeciwieństwie do nich zwykli przestępcy dopuszczają się zbrodni, aby zyskać odpowiedni prestiż określony przez nacisk społeczeństwa; najczęściej chodzi im o korzyści materialne. Sprawcy seryjni natomiast „nie czerpią finansowych korzyści ze swoich zbrodni; w spaczony, jednak czasem zrozumiały sposób szukają emocjonalnej satysfakcji”'3. Termin seryjny zabójca wymyślony został przez agenta Resslera dla określenia takich postaci, jak między innymi: David Richard Berkowitz, Richard Ramirez, Edmund Emil Kemper III, Jeffrey Dahmer.

\footnotetext{
2 A. Czerwiński, K. Gradoń, Seryjni mordercy, Warszawa 2001, s. 17.

3 R. K. Ressler, T. Shachtman, Whoever Fights Monsters, St. Martin's 1993, s. 45.
} 
Warto wspomnieć, że wcześniej funkcjonował już podobny termin, „przestępstwo seryjne” (crimes in series), które używane było przez brytyjskich specjalistów, do określania powtarzających się gwałtów, włamań, podpaleń i innych przestępstw. Robert Ressler jednak je zmodyfikował i przypisał do powtarzających się seryjnych mordów, których sprawcy kierowali się przede wszystkim chęcią urzeczywistnienia swoich zwyrodniałych fantazji. Fantazji, które od chwili pojawienia się są idealizowane w ich umysłach, opracowywane w każdym najmniejszym szczególe. Kiedy jednak dochodzi do próby ich zrealizowania, okazuje się, że nie jest to tak, jakby chcieli, żeby było. A. Czerwiński i K. Gradoń piszą, że morderstwo:

(...) nie jest jednak nigdy tak satysfakcjonujące, jak wygląda w wyobraźni; morderca wkrótce po dokonaniu czynu zaczyna myśleć o tym, że następnym razem mógłby zabić w sposób jeszcze bardziej doskonały4.

\section{Inne zabójstwa wielokrotne}

Z pojęciem seryjne zabójstwo wiążą się również inne pojęcia odnoszące się do zabójstw wielokrotnych. Między innymi mówi się o terminie The Spree killers, które można tłumaczyć jako „zabójstwo impulsywne". W tym przypadku seria morderstw ma charakter sytuacyjny, to znaczy związany bardzo często $\mathrm{z}$ nastrojem lub reakcją zabójcy na jakieś silnie emocjogenne wydarzenie - zabójca może przestać zabijać tak szybko, jak zaczął, tzn. kiedy nastąpi emocjonalne wyciszenie. Co ciekawe, ofiarami zabójców impulsywnych są najczęściej osoby, które znalazły się w nieodpowiednim miejscu, o złym czasie. Działania tego rodzaju przestępców skupiają się zwykle na zabiciu kilku osób w ciągu krótkiego czasu, zazwyczaj kilku godzin. Wspomniane emocjonalne wyciszenie jest pojęciem charakterystycznym także dla tradycyjnych seryjnych zabójców. W ich przypadku następuje ono w przerwach między kolejnymi zabójstwami, co nie ma prawa mieć miejsca w przypadku zabójców impulsywnych, u których okres między kolejnymi

${ }^{4}$ A. Czerwiński, K. Gradoń, Seryjni mordercy..., op. cit., Warszawa 2001, s. 18. 
Mateusz Caban - Seryjne zabójstwo...

zabójstwami jest za krótki, bo wynosi czasami tylko kilka minut emocjonalne wyciszenie wiąże się z przerwaniem zabijania.

Wypada także zwrócić uwagę na ciekawy przypadek zabójców masowych, których działania są „,jednorazowym, ekstremalnym aktem przemocy polegającym na pozbawieniu życia wielu osób jednocześnie i późniejszej autoegzekucji”. Pod względem motywacji nie różnią się oni zbytnio od seryjnych zabójców, ponieważ zbrodnie, które popełniają, mają często charakter buntu przeciwko społeczeństwu. W przeciwieństwie jednak do nich nie szukają sławy, natomiast chwila, w której dokonuje się koniec ich makabrycznego działania, to najczęściej moment, w którym giną od policyjnych pocisków ${ }^{6}$. Ciekawym przykładem zabójcy masowego jest znany chyba na cały świecie Anders Behring Breivik, który w ciągu jednego dnia pozbawił życia 77 osób i 33 ranił. W przeciwieństwie jednak do większości zabójców masowych nie zginął on od policyjnych pocisków, ale przyznał się do przeprowadzenia zamachów i oddał w ręce władz. Powszechnie wiadomo, że jego działania miały motywy polityczne i ideologiczne.

Zabójców masowych można podzielić na trzy kategorie, jak to zrobił T. O’Relly-Fleming: działających i uciekających, którzy dokładnie planują swoje działania, aby później bezpiecznie móc uciec z miejsca przestępstwa - tu przykładem może być Happyland Killer, który dopuścił się podpalenia dyskoteki, po czym uciekł z miejsca zdarzenia; pseudokomandosów, czyli tzw. maniaków władzy, którzy zafascynowani bronią testują swoje umiejętności w trakcie zbiorowego mordu; zabójców chorych psychicznie zabójców, którzy cierpią na różne zaburzenia umysłowe, w wyniku czego dokonują wielu aktów przemocy, a w tym także morderstw 7 .

5 Ibidem, s. 27.

${ }^{6}$ E. Leyton, Polowanie na ludzi, Warszawa 1996, s. 17.

7 T. O'Relly-Fleming, The Evolution of Multiple Murder in Historical Perspectiv, [w:] Tenże, Serial and Mass Murder: Theory, Research and Policy, Canadian Scholar's Press, Toronto 1996, s. 16. 


\section{Motywacja seryjnych zabójców}

Fenomen seryjnych zabójców za każdym razem prowadzi do pytania, jakie są motywy ich działania? Wiadomo, że seryjne zabójstwa nie są popełniane dla zysku w sensie materialnym, ale najczęściej ich głównym celem jest zaspokojenie seksualne, chęć poczucia władzy, albo po prostu sama satysfakcja z pozbawienia życia drugiego człowieka. Poznanie motywacji sprawców oczywiście nie doprowadzi do zrozumienia całego zjawiska. Pomoże jedynie w określaniu portretów psychologicznych sprawców i indywidualnych przyczyn osadzonych w ich osobowościach.

W literaturze naukowej, zarówno polskich jak i zagranicznych autorów, łatwo zauważyć, że najczęściej wymieniane motywy działań seryjnych zabójców to te na tle: seksualnym, emocjonalnym, rabunkowym oraz urojeniowym. W wielu źródłach dodatkowo są one rozszerzone o motywy wizjonerskie, misyjne, hedonistyczne i z lubieżności. W przypadku tych ostatnich warto zwrócić uwagę na stanowisko Jarosława Stukana, który uważa je za podklasę motywów głównych, czyli tych wymienionych wcześniej. Przykładem może być motyw wizjonerski, który według autora jest po prostu motywacją urojeniową. Mordercy kierują się określoną ideą, której nikt poza nimi nie jest w stanie zrozumieć. Wiąże się to $\mathrm{z}$ faktem, że przypisywani są do kategorii zabójców nie mających częściowo kontaktu z rzeczywistością. Podstawą tego są najczęściej zaburzenia paranoidalne osobowości bądź psychoza objawiająca się jako paranoja ${ }^{8}$.

Motywacja rabunkowa w większości źródeł uznawana jest za najmniej związaną z seryjnymi zabójstwami, bo tylko nieliczni sprawcy kierują się możliwością zdobycia dóbr materialnych. Niemniej jest ona obecna i warta poświęcenia kilku zdań, aby lepiej zrozumieć cały temat. W przeciwieństwie do pozostałych typów nie stwarza ona problemów śledczym z określeniem jej charakteru9. Najczęściej już

\footnotetext{
8 J. Stukan, Polscy seryjni mordercy, Prometeusz 2009, s. 30.

${ }^{9}$ Ibidem, s. 31.
} 
Mateusz Caban - Seryjne zabójstwo...

wstępne oględziny miejsca przestępstwa pozwalają stwierdzić, że motywacją sprawcy były korzyści materialne.

Pośród wspomnianych motywacji najbardziej nieokreśloną wydaje się być motywacja emocjonalna. Najczęściej dotyczy ona sprawców pojedynczych zabójstw, ale ma miejsce także w przypadku sprawców seryjnych morderstw, zwłaszcza zabójstw impulsywnych. Przestępcy, wobec których przypisuje się ten rodzaj motywacji, najczęściej zabijają dla zemsty lub w wyniku wydarzenia, które wywołało u nich falę negatywnych emocji. Zdarzają się jednak przypadki, w których to emocje są celem zabijania. Oznacza to, że sprawca dopuszcza się zbrodni, aby zyskać jakieś nowe doświadczenie, osiągnąć przyjemność czy wzrost adrenaliny w wyniku zrobienia czegoś niedopuszczalnego i nielegalnego.

Najczęściej poruszaną i najobszerniej opisywaną w literaturze naukowej jest motywacja seksualna. Wynika z niej mnóstwo problemów podczas prowadzenia śledztwa, często również trudno określić rzeczywisty cel działania przestępców. Należy również wziąć pod uwagę, że przestępcy zabijający swoje ofiary na tle seksualnym tworzą największą grupę pośród seryjnych zabójców ${ }^{10}$.

Motywacja seksualna jest na tyle złożona, że doczekała się wielu modeli, a jeden z nich został stworzony przez polskiego lekarza sądowego Leona Wachholza. W swoim modelu wyróżnił on cztery rodzaje zabójstwa na tle seksualnym: zabójstwo przed podjęciem aktu płciowego, zabójstwo zamiast aktu płciowego, zabójstwo w trakcie aktu płciowego, zabójstwo po akcie płciowym. Zabójstwa na tle seksualnym wiążą się również z pojęciem sadyzmu, ponieważ sprawca zawsze wykorzystuje swoją siłę fizyczną, ofiara zaś zostaje przez niego zdominowana ${ }^{11}$.

Ciekawej klasyfikacji seryjnych zabójców ze względu na rodzaj motywacji do zbrodni, na który warto również zwrócić uwagę, zaproponowali R. M. Holmes i J. E. DeBurger:

10 Ibidem, s. 32.

11 Ibidem, s. 33. 
1. Wizjonerzy - przestępcy tej kategorii popełniają zbrodnie, których podstawą są psychotyczne symptomy, takie jak urojenia czy halucynacje. W przypadku tych przestępców ich ofiary wybierane są na podstawie jakiegoś klucza - może to być rasa, wykonywany zawód, płeć, wiek, czy po prostu przynależność do danej grupy społecznej. Wśród wizjonerów często istnieje przekonanie, że zabijanie określonych ofiar zagwarantuje im miejsce w niebie.

2. Misjonarze - przestępcy tej kategorii występują stosunkowo rzadko. Ich „misja” polega na tym, że przekonani są, iż społeczeństwo musi pozbyć się jakiejś grupy ludzi, na przykład polityków, prostytutek czy nawet jakiejś określonej warstwy społecznej. Niekiedy bywają przekonani, że część ludzi w pełni popiera ich działalność, bo rzekomo mają na celu oczyszczenie społeczeństwa. Co ciekawe, w większości przypadków przestępcy - misjonarze nie przejawiają żadnych oznak chorób psychicznych.

3. Hedoniści - tę grupę można podzielić na trzy rodzaje: zabójcy z lubieżności, czyli mordercy zabijający dla osiągnięcia zaspokojenia seksualnego. Niektóre źródła podają, że w ich przypadku w okresie dzieciństwa musiała mieć miejsce sytuacja, w której doszło do połączenia seksualności z przemocą. Doprowadziło to do tego, że ich seksualne podniecenie jest możliwe wówczas, kiedy ofiara cierpi, kona lub nawet jest martwa. Innymi słowy, zaspokojenie seksualne osiągają dopiero wtedy, kiedy zyskają nad ofiarą przewagę fizyczną, zadając jej ból, a w skrajnych przypadkach uniesienie następuje tylko bezpośrednio $\mathrm{w}$ trakcie pozbawiania ofiary życia. Przestępcy zorientowani na emocje to sprawcy kierujący się wspomnianą już motywacją emocjonalną. Swoje ofiary zabijają dla samego podniecenia, jednak z każdym kolejnym morderstwem zyskują nowe doświadczenie. Zarówno $w$ tej jak i w poprzedniej grupie sprawcy wykazują zachowania sadystyczne. Zalicza się do nich wszelkiego rodzaju techniki okaleczania ofiary, ćwiartowanie zwłok, gotowanie ich, stosunek seksualny zarówno przed jak i po śmierci ofiary. Zabójcy zorientowani 
Mateusz Caban - Seryjne zabójstwo...

na komfort to najrzadsza grupa seryjnych zabójców, ponieważ zabójstwo jest raczej elementem instrumentalnym, a nie jak w poprzednich przypadkach celem samym w sobie. Stanowi środek psychicznej lub częściej materialnej gratyfikacji. Zabójca zaś nie skupia się na całym przebiegu morderstwa, lecz tylko na tym, żeby ofiara została uśmiercona, bo na przykład pozwoli to na przejęcie jej majątku.

4. Maniacy władzy - ich motywacją jest pragnienie osiągnięcia całkowitej kontroli i władzy nad swoją ofiarą. Jeśli zaś dochodzi do aktów seksualnych, to stanowią one raczej przejaw dominacji i niewiele wspólnego mają z zaspokojeniem seksualnym. Sprawca dla swoich ofiar chce być czymś w rodzaju boga. W niektórych przypadkach przestępcy duszą swoje ofiary, a kiedy już tracą przytomność, przywracają je z powrotem do życia. W ten sposób udowadniają swoją władzę nad ich życiem, ofiara ma mieć pewność, że to, czy będzie żyła, zależy tylko od oprawcy ${ }^{12}$.

Należy pamiętać, że różne typy motywacji, które są opisywane przez specjalistów, w żaden sposób nie służą do usprawiedliwiania przestępców zabijających ludzi. Służą one przede wszystkim do racjonalizacji zbrodni, pomagają zrozumieć i usystematyzować zjawisko seryjnego zabójstwa. Typy motywacji pozwalają również na szybsze działanie organów ścigania, bowiem każda wskazówka może się przyczynić do szybszego ujęcia sprawcy. Motywacja seryjnych zabójców wciąż jednak nie wyjaśnia, jakie czynniki zewnętrzne doprowadzają do tego, że sprawcy są w stanie dokonywać tak zwyrodniałych czynów - tego już należy szukać w ich dzieciństwie i wpływach środowiska zewnętrznego.

${ }^{12}$ A. Czerwiński, K. Gradoń, Seryjni mordercy..., op. cit., s. 66-67. 


\section{Wpływ środowiska zewnętrznego oraz dzieciństwo seryjnych zabójców}

W większości życiorysów seryjnych zabójców poświęca się dużo miejsca na opis ich dzieciństwa oraz wpływu czynników zewnętrznych, co oznacza, że oba te elementy mają istotny wpływ na ich działania. Nie ma przecież wątpliwości co do tego, że dzieciństwo i okres adolescencji jest najważniejszym w całym życiu człowieka, a niepoprawne oddziaływanie na psychikę w tym czasie może wywołać późniejsze negatywne konsekwencje. Natomiast środowisko zewnętrzne niemal bez przerwy oddziałuje na jednostkę, wymuszając określone postępowanie, co może być $w$ wielu przypadkach przyczyną, długotrwałej frustracji, niezadowolenia i wreszcie agresji.

Pamiętać trzeba, że człowiek jest wytworem społeczeństwa, bez którego nie byłby w stanie rozwinąć wszystkich właściwości charakterystycznych dla swojego gatunku. Taki rozwój oparty jest na określonych warunkach i zasadach, które ukazują się w określonym wpływie na jednostkę. Oznacza to, że pewne doświadczenia społeczne $\mathrm{w}$ połączeniu $\mathrm{z}$ indywidualnymi predyspozycjami, mają wpływ na to, jakimi wartościami człowiek będzie się kierował i jakie potrzeby staną się dla niego priorytetowe ${ }^{13}$. Człowiek jest poddawany ciągłemu naciskowi ze strony społeczeństwa, które narzuca mu ogólnie uznane cele, do których powinien dążyć i uczy go także, jakich środków może użyć, aby je osiągnąć. Pojawia się więc problem, a mianowicie - nie każdy ma równy dostęp do takich środków, przez co nie może osiągnąć narzuconych celów i zyskać odpowiedniego prestiżu. Aby więc osiągnąć określone cele, jednostka posuwa się do wykorzystania środków uznawanych za ogólnie niedopuszczalne. Przykładem mogą być przestępstwa na tle seksualnym - sprawca nie może osiągnąć osobistego spełnienia, którym w tym przypadku jest zaspokojenie seksualne, więc postanawia osiągnąć cel na drodze przestępstwa, jakim jest

13 J. Błachut, A. Gaberle, K. Krajewski, Kryminologia, Gdańsk 2004, s. 70. 
Mateusz Caban - Seryjne zabójstwo...

na przykład gwałt. Taki sposób osiągania celów środkami niedopuszczalnymi w kryminologii nazywa się „innowacją” 14.

Wpływ środowiska zewnętrznego na seryjnych zabójców i przestępców w ogóle wyjaśnia również tzw. koncepcja społecznego uczenia się agresji, której ojcem jest Albert Bandura. W swoich badaniach skupił się przede wszystkim na genezie agresji i podzielił ją na trzy płaszczyzny. Pierwsza z nich to mechanizm nabywania wzorców zachowań agresywnych, czyli po prostu uczenie się agresji poprzez obserwację innych ludzi. Mechanizm ten jest możliwy dzięki określonym źródłom agresji i przemocy, które biorą się ze środowiska rodzinnego, środowiska społecznego, w którym człowiek się rozwija oraz ze środków masowego przekazu. Druga płaszczyzna to już mechanizm wyzwalania zachowań agresywnych. Zaobserwowane i wyuczone zachowania agresywne - co ma miejsce w poprzedniej płaszczyźnie pozostają w spoczynku tak długo, aż nie pojawi się odpowiedni bodziec, który je wyzwala. Do bodźców tych zalicza się: czynniki awersyjne, czyli wszelkie sytuacje wywołujące u człowieka strach, frustrację, złość i inne negatywne emocje prowadzące dalej do agresji; czynniki instrumentalne, które mają miejsce wówczas, kiedy jednostka wie, że za pomocą agresji osiągnie jakieś korzyści; czynniki modelujące - agresywne zachowanie się innych osób, wpływa na to, że jednostka również zaczyna zachowywać się $\mathrm{w}$ ten sam agresywny sposób. I trzecia płaszczyzna to mechanizmy podtrzymujące zachowania agresywne. Największe znaczenie mają tu wzmocnienia zewnętrzne określone zachowania agresywne dają jednostce jakieś korzyści w postaci zysków materialnych, psychicznych lub też działając jako nagroda, redukując negatywne sytuacje ${ }^{15}$.

Dzieciństwo, jak wcześniej zostało wspomniane, to bardzo ważny okres w rozwoju człowieka, a negatywne czynniki mające wpływ na dziecko w tym czasie mogą się odbić w jego późniejszym życiu. W odniesieniu do seryjnych zabójców trzeba podkreślić, że u większości

\footnotetext{
14 A. Czerwiński, K. Gradoń, Seryjni mordercy..., op. cit., s. 335-336.

15 J. Błachut, A. Gaberle, K. Krajewski, Kryminologia..., op. cit., s. 286-287.
} 
z nich dzieciństwo wpływało bardzo niekorzystnie na ich rozwój. Wielu z nich było molestowanych seksualnie przez ojca, było świadkami znęcania się ojca nad matką czy też ich ciągłych kłótni. W ich rodzinach często nadużywany był alkohol i inne substancje odurzające, w tym także narkotyki. Oczywiście koncepcja mówiąca o tym, że dzieciństwo ma jakikolwiek wpływ na działalność seryjnych morderców, spotyka się z krytyką ze strony wielu naukowców. Powód jej jest taki, że nie ma stosownych badań, które potwierdzałyby wpływ dzieciństwa na dorosłe życie sprawców. Zdania w tej kwestii jednak są podzielone i część naukowców uważa, że brak dowodów wcale nie oznacza, iż taki wpływ nie istnieje. Pojawia się pytanie, dlaczego takie badania nie zostały przeprowadzone? Otóż przeprowadzenie badań na odpowiedniej ilości seryjnych zabójców jest niezwykle trudne, ponieważ na przestrzeni kilku lat jest ich niewielu w stosunku do potrzeb badawczych, więc prawdopodobnie jednemu badaczowi nie starczyłoby życia na wykonanie odpowiednich badań. Dodatkowym utrudnieniem jest fakt, że każdego sprawcę trzeba traktować jako indywidualny przypadek.

Należy w tym momencie wspomnieć o badaniach przeprowadzonych przez agentów FBA, które miały na celu analizę dzieciństwa seryjnych morderców. Wprawdzie badania przeprowadzone zostały na zaledwie 36 przestępcach, z czego tylko 25 było seryjnymi zabójcami, to jednak dają one ogólny pogląd na sytuację i świadczą o możliwym wpływie dzieciństwa. Specjaliści uzyskali wyniki, z których wynika między innymi, że 12 z 28 badanych sprawców było molestowanych seksualnie oraz 13 z 31 doświadczyło przemocy fizycznej ze strony rodziców, 23 z 31 również psychicznej. Część sprawców (40\%) często przebywało w domach dziecka i innych tego typu placówkach, również w szpitalach psychiatrycznych - aż 25 z 36 sprawców było leczonych psychiatrycznie, jednak nie oznacza to, że chorowali psychicznie. Wiele rodzin sprawców często zmieniało miejsce zamieszkania, co przyczyniało się do tego, że dzieci nie mogły utrzymać stałych i pozytywnych relacji z rówieśnikami. Mogło to być przyczyną wspo- 
Mateusz Caban - Seryjne zabójstwo...

mnianego wcześniej odczucia braku przynależności do grupy społecznej, izolacji od społeczeństwa i wreszcie uczucia odrzucenia. Z przeprowadzonych badań wynikło również, że w wielu rodzinach sprawców obecne były także inne negatywne czynniki, takie jak: problemy alkoholowe w 69\% przypadków, u połowy przeszłość kryminalna, uzależnienie od narkotyków obecne w 33,3\% rodzin, a także problemy seksualne w 46,2\% przypadków ${ }^{16}$.

Jakkolwiek nie wszystkie czynniki mogą mieć bezpośredni wpływ na postępowanie seryjnych zabójców, to część z negatywnych sytuacji, które w kolejnych latach życia nie uległy zatarciu, jak na przykład izolacja społeczna, zaburzenia psychiczne, które mogły nawet ulec pogłębieniu, z pewnością taki wpływ wywierały.

Podsumowując tę część, warto zwrócić uwagę na przemyślenia Carla Panzarma, seryjnego zabójcy uznanego za ponadprzeciętnie inteligentnego. Uważał on bowiem, że człowiek będzie żył w taki sposób, w jaki został nauczony. Głównym zaś powodem, dlaczego seryjni zabójcy i inni przestępcy dopuszczają się zbrodni, jest niewłaściwe ich wychowanie oraz wpływ środowiska. Carl odniósł się również do własnego przypadku, wspominając o swoich rodzicach, których określił jako ignorantów. Przez ich niepoprawne wychowywanie oraz niewłaściwe środowisko coraz bardziej schodził na złą drogę. Umieszczenie w poprawczaku w wieku 11 lat uważa za początek stawania się coraz gorszym. Biorąc pod uwagę, że w takim wieku był wystawiony na oddziaływanie pozostałych umysłowo i moralnie nieprzystosowanych osadzonych, nie miał szans na stanie się lepszym - bo na podstawie jakich wzorców? Jak piszą Czerwiński i Gradoń, Carl został pozbawiony pozytywnych wzorców i wychował się na zepsuciu, okrucieństwie i zemście ${ }^{17}$. Trafiał z jednego demoralizującego środowiska do kolejnych - jeszcze gorszych. Taki przebieg dzieciństwa mógł więc być jedną z przyczyn jego zwyrodniałych działań, podobnie jak w przy-

\footnotetext{
16 J. Stukan, Polscy seryjni mordercy..., op. cit., s. 14-16.

17 A. Czerwiński, K. Gradoń, Seryjni mordercy..., op. cit., s. 112.
} 
padku innych seryjnych zabójców, których dzieciństwo i okres adolescencji miały podobnie negatywny przebieg.

\section{Możliwości resocjalizacyjne seryjnych morderców}

W obecnej praktyce penitencjarnej nie przewiduje się jakichś szczególnych oddziaływań resocjalizacyjnych wobec sprawców zabójstw ${ }^{18}$. Powszechnie za najważniejsze i najczęściej podejmowane działania uważa się izolację, czego przykładem są orzekane długoterminowe wyroki w stosunku do tej kategorii przestępców. W niektórych krajach, zwłaszcza w Stanach Zjednoczonych, sąd orzeka najczęściej karę śmierci w stosunku do seryjnych morderców, jeżeli oczywiście zostaną uznani za poczytalnych w trakcie popełniania morderstw - wyjątkiem był Albert Hamilton Fish, który mimo uznanej niepoczytalności, został skazany na karę śmierci z powodu okrucieństwa czynów. Zdarzają się również sytuacje, że niektórzy sprawcy seryjnych morderstw opuszczają mury zakładów karnych, mimo że popełnione przez nich czyny kwalifikują ich na karę dożywotniego pozbawienia wolności. Przykładem takiego przestępcy może być Mariusz Trynkiewicz, który mimo wagi swoich czynów i początkowej kary dożywotniego pozbawienia wolności wyszedł z więzienia po 25 latach. Taka sytuacja pokazuje, że należy zwrócić uwagę na seryjnych zabójców, którzy przed czasem mogą opuścić jednostki izolacyjne. Jeśli weźmiemy pod uwagę fakt, że dla społeczeństwa byli niebezpieczni jeszcze przed zamknięciem w zakładzie karnym, to w trakcie długotrwałej izolacji, bez odpowiedniej terapii resocjalizacyjnej, wątpliwe jest, by ich postawa zmieniła się na lepsze. Dlatego też nie można pozostać przy samej izolacji penitencjarnej, ale konieczne jest podjęcie wobec sprawców seryjnych morderstw odpowiednich działań resocjalizacyjnych.

18 M. Kowalczyk-Janicka, Modelowe ujęcie sprawców zabójstw i możliwości ich resocjalizacji, [w:] T. Sołtysiak, A. Latoś (red.), Działalność profilaktyczna i resocjalizacyjna $w$ środowisku otwartym, instytucjach wychowawczych, poprawczych oraz karnych, Bydgoszcz 2010, s. 152-176. 
Mateusz Caban - Seryjne zabójstwo...

Ze sprawą seryjnych zabójców wiąże się też szeroko rozwinięty, wspomniany już, problem ich poczytalności, który trzeba brać pod uwagę podczas ustalania wyroku. Pamiętać należy, że w większości krajów odpowiedzialność sprawcy za popełniane przez niego czyny zależy właśnie od stopnia jego poczytalności w trakcie popełniania tych czynów. Okazuje się jednak, że, jak twierdzą specjaliści, w większości przypadków seryjni zabójcy są poczytalni. Często stwierdzane u nich zaburzenia osobowości nie są podstawą do uznania ich za niepoczytalnych, chociaż i w tym przypadku znajdą się przeciwnicy. Przestępcę można uznać za niepoczytalnego tylko wówczas, kiedy stwierdzi się u niego zaburzenia psychotyczne bądź urojeniowe, a to zdarza się stosunkowo rzadko.

Seryjni zabójcy są specyficzną kategorią przestępców ze względu na destrukcyjny charakter ujawnianych przez nich cech. Wyraźnie rozpoznawalne zaburzenia osobowe, zaburzenia identyfikacji i preferencji seksualnych niosą za sobą konieczność podjęcia długotrwałych i wielowymiarowych form resocjalizacji. W większości przypadków poziom zaburzeń jest na tyle zaawansowany i szeroki, że rokowania na powodzenie terapii uznaje się za niekorzystne. Należy również wziąć pod uwagę wysoce ukształtowaną obsesję zabijania, powstającą w wyniku predyspozycji wrodzonych, przeżytej traumy bądź pod wpływem niewłaściwie ukształtowanych więzów emocjonalnych z najbliższymi. Niewłaściwe wychowanie może być przyczyną niskiej samooceny i poczucia własnej wartości, co w perspektywie dłuższego czasu może skutkować pojawieniem się fantazji o krzywdzeniu i zabijaniu. Obsesja zabijania sprawia, że z chwilą, gdy nastąpi wyciszenie emocji wywołanych ostatnim morderstwem, pojawia się chęć popełnienia następnego. Wobec tego działania podejmowane w stosunku do zabójców muszą być ukierunkowane na redukowanie czynników wywołujących zbrodnicze zachowania. Ważne również jest, aby wykształcić umiejętność wytwarzania wewnętrznej blokady moralnej u przestępcy, która skutecznie będzie powstrzymywała go przed dokonywaniem kolejnych zbrodni. Aby tego dokonać, trzeba odnaleźć i ustalić wszystkie sytuacje, które poprzedzają popełnione zbrodnie 
i mogą mieć z nimi związek. Sprawca powinien sobie uświadomić i nauczyć się rozpoznawać sytuacje spustowe, które interpretowane są przez jego umysł jako siła popychająca do zabicia. To wszystko jest oczywiście możliwe tylko wówczas, gdy morderca z własnej woli chce współpracować i poddać się terapii resocjalizacyjnej ${ }^{19}$.

Istotnym posunięciem $\mathrm{w}$ trakcie terapii jest redukcja bardzo wysokiego poziomu agresji, która stanowi przyczynę popełnianych zbrodni. Sprawca musi nauczyć się panować nad emocjami i rozpoznawać pierwsze sygnały bodźców spustowych, prowadzących do wybuchu agresji. Podstawą do skutecznego oddziaływania resocjalizacyjnego jest właśnie wypracowanie i utrwalenie umiejętności skutecznego rozpoznawania i panowania nad negatywnymi emocjami. Niezwykle korzystny wpływ na powodzenie terapii ma odnowa relacji rodzinnych czy nawet ich budowa od podstaw. Należy pamiętać, że w przypadku seryjnych zabójców charakterystyczne dla nich były najczęściej negatywne relacje $\mathrm{z}$ rówieśnikami, a to szło $\mathrm{w}$ parze $\mathrm{z}$ niską pozycją w grupie. Niestety sprawcy zwykle nie potrafią wskazać osoby, z którą łączyły ich jakiekolwiek więzi przyjacielskie, a jeśli już takowe były, to miały one raczej charakter powierzchowny i nietrwały do tego stopnia, że po ujawnieniu zbrodniczych czynów ulegały całkowitej destrukcji. Warto zwrócić uwagę również na osoby uzależnione, na przykład od alkoholu. W takim przypadku często okazuje się, że to właśnie on był czynnikiem spustowym, zwalniającym wszelkie hamulce. Wobec tego proces resocjalizacji powinien brać pod uwagę również leczenie uzależnieńn ${ }^{20}$.

Wśród seryjnych zabójców znajduje się wiele niezwykle inteligentnych i wykształconych jednostek, jednakże są również tacy, którzy takiego wykształcenia nie mają. Warto więc zadbać o możliwość rozwoju i edukacji, ale jednocześnie wytworzyć chęć i motywację do korzystania $\mathrm{z}$ nauki. Udział $\mathrm{w}$ różnego rodzaju zajęciach edukacyjnych, czy nawet zdobywanie kwalifikacji zawodowych, pomoże w nabraniu

\footnotetext{
19 Ibidem.

20 Ibidem.
} 
Mateusz Caban - Seryjne zabójstwo...

szacunku do wszelkich norm społecznych i przede wszystkim do poszanowania ludzkiego życia. Kształcenie zawodowe natomiast pomoże w podniesieniu własnej wartości, a w przyszłości da możliwość samodzielnej egzystencji w przypadku ewentualnego zwolnienia z zakładu karnego.

Poza edukacją i rozwojem intelektualnym bardzo ważny jest również wysiłek fizyczny w postaci różnego rodzaju zajęć sportowych. Jest to jeden z najlepszych sposobów na wyładowanie negatywnych emocji, zwłaszcza agresji, daje również poczucie przynależności do określonej grupy. Dla przestępców przejawiających agresję, zaburzoną samoocenę bądź niepoprawne mechanizmy obronne uruchamiane w sytuacjach dla nich trudnych należy przewidzieć działania mające charakter oddziaływań terapeutycznych i psychokorekcyjnych, a $\mathrm{w}$ tym różne formy psychoterapii oraz terapię grupową. Wobec sprawców, u których zdiagnozowano wysoki poziom agresji należałoby przewidzieć udział w zajęciach treningowych, które zredukują skłonności agresywne, jak np. udział w Treningu Zastępowania Agresji. W przypadku zaburzonej samooceny pomocne może być uczestnictwo we wszelkich formach treningowych, które przywrócą poprawną samoocenę. Podobnie w przypadku niepoprawnych mechanizmów obronnych pomóc mogą zajęcia terapeutyczne mające charakter antystresowy, modyfikujące nieadekwatne postawy obronne w sytuacjach trudnych. Niezbędne jest ponadto zapewnienie wszelkiego rodzaju zajęć warsztatowych, zajęć z psychodramy bądź arteterapii, które pomagają $w$ nauce konstruktywnego wyrażania emocji, budują poczucie empatii i co ważne, pozwalają wczuć się sprawcy w sytuację ofiary. Niestety, zwrócić należy uwagę, że podjęcie tego typu działań jest całkowicie uzależnione od możliwości poszczególnych placówek penitencjarnych, jak również od zapewnienia bezpieczeństwa innym osadzonym, wychowawcom i psychologom oraz od zagrożenia, jakie mogą sprawiać poszczególni przestępcy.

W praktyce penitencjarnej podejmowane działania resocjalizacyjne powinny uwzględniać wielowymiarowy charakter dokonywanych zabójstw przez sprawców wspomnianej kategorii, z uwzględnieniem 
jednocześnie ich sytuacji życiowej. Oddziaływania resocjalizacyjne winny skupiać się na zminimalizowaniu ryzyka ponownego popełniania zbrodni przez sprawców, a także umożliwienie powrotu do społeczeństwa po odbyciu kary, uwzględniając negatywne konsekwencje długotrwałej izolacji, będące wynikiem prizonizacji. Zwrócić należy uwagę na czynniki wywołujące niepożądane zachowania, które stwarzają zagrożenie popełniania przestępstw seryjnych i przypisać im odpowiednie działania, które je zneutralizują. Najważniejszym jednak warunkiem, dającym podstawy do jakichkolwiek rezultatów jest wytworzenie u przestępców odpowiedniej motywacji.

Resocjalizacja wobec seryjnych zabójców może zostać uznana za optymistyczną już wówczas, kiedy sprawcy zrozumieją negatywne skutki popełnionych przez nich zbrodni, uświadomią sobie własną winę i zaczną odczuwać wyrzuty sumienia. Bardzo pozytywny wydźwięk będzie miało duże, a nawet tylko umiarkowane zainteresowanie $\mathrm{z}$ ich strony i udział $\mathrm{w}$ terapii oraz zaangażowanie się we wszelkie formy działań resocjalizacyjnych. Ważnym wyznacznikiem powodzenia procesu będą poczynione postępy w zakresie zdobywanych umiejętności społecznych i uczestnictwo w terapii uzależnień w przypadku osób uzależnionych. Oczywiście należy brać pod uwagę możliwość niepowodzenia oddziaływań resocjalizacyjnych. Wówczas najważniejszą i najlepszą formą resocjalizacji będzie długotrwała izolacja więzienna. Nie tylko stanowi ona ochronę społeczeństwa przed sprawcą, ale także chroni samego zabójcę przed możliwym samosądem ze strony społeczeństwa. Istnieje również ryzyko, że nawet po pozornie udanym procesie resocjalizacji sprawca seryjny po wyjściu na wolność powróci do swojej zbrodniczej działalności. Nakładanie kary powinno więc uwzględniać okrutnie destrukcyjny charakter zbrodni, antyspołeczną postawę przestępcy i często przejawianą osobowość psychopatyczną. W polskim wymiarze sprawiedliwości karą dla seryjnych zabójców powinno być bezwzględnie dożywotnie pozbawienie wolności. 
Mateusz Caban - Seryjne zabójstwo...

\section{Bibliografia:}

Błachut J., Gaberle A., Krajewski K., Kryminologia, Wyd. Arche, Gdańsk 2004. Czerwiński A., Gradoń K., Seryjni mordercy, Wyd. Muza, Warszawa 2001. Leyton E., Polowanie na ludzi, Wyd. Al Fine, Warszawa 1996.

Kowalczyk-Jamnicka M., Modelowe ujęcie sprawców zabójstw i możliwości ich resocjalizacji, [w:] T. Sołtysiak, A. Latoś (red.), Działalność profilaktyczna i resocjalizacyjna $w$ środowisku otwartym, instytucjach wychowawczych, poprawczych oraz karnych, Wyd. Uniwersytetu Kazimierza Wielkiego, Bydgoszcz 2010.

Kowalczyk M. H., Zabójcy i mordercy. Czynniki ryzyka i możliwości oddziaływań resocjalizacyjnych., Wyd. Oficyna Wydawnicza Impuls, Kraków 2010.

Ressler R. K., Shachtman T., Whoever Fights Monsters, St. Martin's 1993.

Stukan J., Polscy seryjni mordercy, Wyd. Prometeusz 2009.

https://www.researchgate.net/publication/261638268 